\title{
The Competency of Distance Learning Educators and Effective Applications of E-Learning in Distance-Learning Schools.
}

\author{
Ugomma Ebirim Ph.D. \\ Department of Adult Education, University of Nigeria
}

\begin{abstract}
This study focused on the identification of required competencies of distance learning educators and effective application of e-learning in distance education in Nsukka, Nigeria. Three research questions and one null hypothesis were formulated to guide the study. Descriptive survey was design and adopted for the study. A structured questionnaire developed by the researcher was used for data collection. Random sampling technique by balloting was applied in selecting 267 respondents out of the 510 population. The instrument was validated by Mr. okpashi E.A of distance education, Nsukka. Cronbach alpha was used to test the internal consistency of the instrument and the reliability co-efficient was 0.71 . Mean and standard deviation were used to analyze the data collected while t-test 0.05 degree of significance at confidence interval was adopted in testing the hypothesis. The results indicated that all the keyboard items were required by distance educators to be able to apply E-learning; that distance educators require all the variables in question two to be able to upload and download instructional materials on the internet. The results in the areas of application, showed that e-learning can be applied in every area of education while the hypothesis result showed that there is no significant difference in the mean rating of distance educators and learners on the competencies require for the application of e-learning. Some recommendations arising from the findings are: Distance educators should have a good grasp of the computer keyboards to be able to function effectively in the world of information and communication Technology which e-learning is parts of. Distance Educators and Learners should be knowledgeable in computer to be able to upload and download instructional materials from the Internet, $C D$ ROMs, and Flash Drives.
\end{abstract}

Key words: Distance learning education, Competency and computer application.

\section{Introduction}

Distance learning Education (DLE) is a system of education in which instruction is made available through a variety of media other than face-to-face which include print, audio, ICT, etc. to those learners who may wish to improve upon their formal education or upgrade their knowledge. Distance Education is a mode of providing education to non-residential basis and learners who are home base. In justifying the needs for DLE, Schaayan (2000) gave nine reasons, which include to have courses for students to learn in different communities covering scanned population, large geographical areas such as Canada and North America, for the training of teachers who are already working and cannot be taken away for some weeks.

Competency on the other hand is described by International Labour Organization (2003) as knowledge, capabilities, skills and behavior exhibited by someone in carrying out his/her job which are factors in achieving the goals relevant to the teaching strategies. In his view, Lucia \& Lepsinger (1999) says competency is a cluster of related knowledge, attitudes, and skills that affects a major part of one's job, role, or responsibility. Therefore, Competency refers to the knowledge, skills and attitudes which distance educators require for effective application of E-learning in DLE.

Dichantz (2001) view e-learning as the collection of teaching and information in further education which is available at any time and any location delivered to learners electronically. Hedge and Hyward (2004) posited that e-learning as an on-line-based learning technique that made possible by computer, internet and other communication and networking facilities. E-learning according to them is the frontiers of DLE by increasing access to learning materials. E-learning is an innovative approach for delivering electronically.

Distance education programs act as catalyst for institutional innovation (Oblinger, 2000) and (Jedlicka et al, 2002), (Blackmore et al, 2007), especially if the instructor is knowledgeable and skilled (Orr, 2010). Elearning as one of the new modes of teaching and learning in the developed world was designed to democratize, revolutionize and expand education at all levels. The influence of e-learning in DLE will increase access to educational technological opportunities. There is certain hardware packages used in e-learning which require some degree of competence for its application.

These hardware's include the computer, CD Rom, keyboard, flash drive and memory card. These will offer interactive learning environment which will enable the learners acquire and receive results within seconds or minutes. Human and material resources are needed for online but e-learning reaches a greater number of 
people making it cost effective. E-learning will provide education at a reduced cost as human and materials requires would have been overcome by on-line system. To achieve this, will largely depend on the competency the educators possess. Certain level of competency would enable have mastery of the keyboards, be able to assess the internet. The dearth of major physical facilities required by the distance educators for the optimization of DLE is a problem in Enugu state. Such physical facilities as computers, internet technical experts, constant power supply, computer skills possessed by the educators and competency required by the distance educators.

The computer as described by Onugha (2006) is an electronic technological device that accepts data and instruction, processes the data as instructed by the user, stores the processed data and displays the outcome in a manner the user will understand. DLE as a type of education where the tutors and learners are separated physically by time and space has many and varied modes of delivery. E-learning which is one of the modes requires some degree of competency by users to be able to apply it effectively in DLE.

In order to enjoy the usefulness of e-learning and apply it effectively in DLE, the distance educators and their learners should have mastery of the computer and its accessories.

\section{Purpose of the Study}

The purpose of this study is to investigate the competency of distance educators for effective application of e-learning in Distance Education. While the following are kept in perspective (1) investigating the competencies required by Distance Educators for maneuvering the computer and it accessories (2) find out the competence of distance educators for internet assessment; (3) to investigate areas where e-learning can be used in DLE.

\section{Research Questions and Hypothesis}

The following research questions and hypothesis guided the study:

1. What are the attributes of a good computer operator in DLE?

2. How is the proficiency of a computer analyst ascertained in relation to internet users and DLE?

3. What are the areas where e-learning can be applied in DLE?

HO1: There is no significant different $(\mathrm{P} \leq 0.5)$ between the mean rating of distance educators and learners on the competencies required for the application of e-learning in DLE.

\section{Significance of the Study}

The findings of the study will increase educational development process in many ways. When the competencies are identified, adult learners will gain more, as they now know what they require to apply elearning as one of their modes of study.

The findings of the study will expose the distance educators on the competency they require to upload and download information from the Net. The findings will as well assist both the distance educators and their learners to determine areas where e-learning can be applied in distance education. The findings will equally assist organizers of or the board of distance education so as to plan on how to solve the problems.

\section{Methodology}

The study used the descriptive survey design method to establish the required competencies by distance educators for effective application of e-learning in the optimizing of DLE. The area of the study is Nsukka educational zone of Enugu State. The population of the study is made up 510 respondents consisting of 63 distance educators and 447 learners from the national training institute (NTI) centers in Nsukka education zone (NTI/2011). A sample size of 204 learners were selected out of the 447 learners through simple random sampling technique by balloting while the 63 distance educators were used making a total of 267 respondents.

The instrument is named the Required Competencies of Distance Educators on the Application of Elearning (RCDEAEL). The instrument was structured on 4 point scale of Strongly Agree (SD), Agree (A), Disagree (D), and Strongly Disagree (SD). The items on the instrument were derived from the research questions based on the purpose of the study. The instrument was face validated by Mr. okpashi, V.R., Mrs. Victoria Adie and John N. D.; one is Computer Education, one in Distance Education and one in measurement and Evaluation, from the Faculty of Education, University of Nigeria Nsukka respectively. The validated instrument was pre-tested to obtain the reliability of the instrument using Cronbach Alpha. The reliability coefficient was 0.71 which indicates reliability of the instrument. One research assistant was trained to help in administration and collection of instrument. The data collected were analyzing the hypothesis formulated for the study. The probability level was set at 0.05 . The items with a mean value of 2.5 and over are regarded as agreed (A), while item with a mean value less than 2.5 are regarded as not required or not accepted. 
The results are presented on Table 1-4.

\section{Results}

\section{Research Question One}

What are the attributes of a good computer operator in DLE?

Mean ratings of the respondents on the competencies required by Distance Educators for maneuvering the computer keyboards. (X-Mean, SD Standard Deviation).

Table 1

Competencies required by distance educators to maneuver the computer keyboards

$\mathrm{S} / \mathrm{N} \quad$ Competencies for Maneuvering Keyboards

\begin{tabular}{|c|c|c|c|c|c|c|c|}
\hline & $(\mathrm{N}=63)$ Learners $(\mathrm{N}=204)$ & $\mathrm{X}$ & $\mathrm{SD}$ & Dec. & $\mathrm{X}$ & SD & Dec \\
\hline 1. & Ability to identify the Keyboards & 3.43 & 0.70 & A & 3.45 & 0.67 & A \\
\hline 2. & $\begin{array}{l}\text { Elbows hand freely } \\
\text { and bent at } 90 \text { degree } \\
\text { when extending the } \\
\text { keyboard. }\end{array}$ & 2.72 & 1.10 & A & 2.71 & 1.02 & A \\
\hline 3. & $\begin{array}{l}\text { Keep hands and wrists } \\
\text { straight when you are } \\
\text { using the kevboard. }\end{array}$ & 2.57 & 0.97 & $\mathrm{~A}$ & 2.53 & 1.13 & A \\
\hline 4. & $\begin{array}{l}\text { Fingers lightly touch the } \\
\text { home row keys }\end{array}$ & 3.14 & 0.92 & A & 3.22 & 0.93 & A \\
\hline 5. & $\begin{array}{l}\text { Stroke the key and the } \\
\text { space bar with your } \\
\text { fingertips not allowing } \\
\text { the force of wrist and arms }\end{array}$ & 3.27 & 0.89 & A & 3.25 & 0.88 & A \\
\hline 6. & $\begin{array}{l}\text { Hands are relaxed in their } \\
\text { Neutral positions. }\end{array}$ & 3.12 & 0.98 & A & 3.24 & 0.85 & A \\
\hline 7. & $\begin{array}{l}\text { Stroke the key lightly and } \\
\text { Firmly allowing your fingers } \\
\text { To move easily. }\end{array}$ & 3.36 & 0.80 & $\mathrm{~A}$ & 3.26 & 1.87 & A \\
\hline 8. & $\begin{array}{l}\text { The key boards is squarely } \\
\text { in front of your body with } \\
\text { easy reach. }\end{array}$ & 3.23 & 0.84 & A & 3.03 & 1.06 & A \\
\hline 9. & $\begin{array}{l}\text { Typing without looking } \\
\text { at the keyboards }\end{array}$ & 2.91 & 1.05 & A & 2.88 & 1.18 & A \\
\hline 10. & Identifying common pointing & 2.89 & 1.13 & A & 2.98 & 1.01 & A \\
\hline
\end{tabular}

Devices such as the mouse

or touch pad.

Grand mean

$\begin{array}{llllll}2.87 & 1.06 & \text { A } & 2.87 & 1.06 & \text { A }\end{array}$

Table 1, shows the responses of both the distance educators and learners on the competencies required by distance educator for maneuvering the computer keyboards to be able to use it for effective application of elearning in DE. The data reveal that all the items have mean scores of 2.5 and above which shows that, they are all accepted as the required competencies for maneuvering the computer keyboards to be at ease with the application of e-learning in DE.

\section{Research Question Two}

How is the proficiency of a computer analyst ascertained in relation to internet users and DLE?

\section{Table 2}

Required competencies by distance educators for uploading their instructional materials on the internet $\mathrm{S} / \mathrm{N} \quad$ Competencies for Uploading Instructional Materials Net
Tutors ( $\mathrm{N}=63)$ Learners $(\mathrm{N}=204)$
$X \quad$ SD $\quad$ Dec. $X \quad$ SD $\quad$ Dec
11. Ability to check all cable
$\begin{array}{llllll}2.72 & 1.01 & \text { A } & 2.68 & 0.99 & \text { A }\end{array}$
Connection to parts in
Backspace to make sure
They are correct
12. Boot the computer correctly.
$\begin{array}{llllll}2.97 & 1.07 & \text { A } & 2.78 & 1.18 & \text { A }\end{array}$
13. Can easily connect to
Internet
14 Ability to browse freely on
$\begin{array}{llllll}2.82 & 1.06 & \text { A } & 2.73 & 1.07 & \text { A }\end{array}$ 
The internet

15. Ability to create a temporary

$\begin{array}{llllll}3.21 & 0.91 & \mathrm{~A} & 3.15 & 0.96 & \mathrm{~A}\end{array}$

File/folder by opening

Windows explorer.

16. Ability to select file or

Folder.

17 Ability to use appropriate

Search engine.

18. Ability to arrange either the

Topic or title which you want

To upload

19. Ability to design a web page

20. Ability to choose the

Correct internet provider.

21. Ability to log on to any

programme on the internet.

22. Ability to install

$\begin{array}{llllll}3.04 & 1.06 & \mathrm{~A} & 3.06 & 1.03 & \mathrm{~A}\end{array}$

$\begin{array}{llllll}2.94 & 1.04 & \mathrm{~A} & 3.01 & 1.02 & \mathrm{~A}\end{array}$

$\begin{array}{llllll}3.15 & 0.98 & \mathrm{~A} & 3.13 & 0.89 & \mathrm{~A}\end{array}$

Auto run programmes.

23. To operate components of

folders and window.

Grand mean

$3.14 \quad 0.96$ A

$3.13 \quad 1.07 \quad A$

The data on table 2 reveal that, the 13 items are accepted as the required competences for uploading of instructional materials on the internet - since each of the items scored more than 2.5 and above.

\section{Research Question Three}

What are the areas e-learning can be applied in DE?

\section{Table 3}

Mean rating of responses on the areas of application of e-learning in DE.

$\mathrm{S} / \mathrm{N} \quad$ Areas of e-Learning Application

Tutors $(\mathrm{N}=63)$ Learners $(\mathrm{N}=204)$

24. Creating greater varieties

$\begin{array}{cccccc}X & \text { SD } & \text { Dec. } & \text { X } & \text { SD } & \text { Dec } \\ 2.86 & 1.06 & \text { A } & 2.94 & 1.08 & \text { A }\end{array}$

Of learning resources

25. Achieve greater interactive

$\begin{array}{lllll}3.04 & 1.00 & \mathrm{~A} & 3.09 & 1.97 \quad \mathrm{~A}\end{array}$

Learning environment

26. Areas of teaching and

Learning on-line.

27. Areas that make learners

To acquire and receive results

Within seconds or minutes

28. When to cater for

$\begin{array}{llllll}3.35 & 0.76 & \text { A } & 3.32 & 0.94 & \text { A }\end{array}$

Personal interest and

Performance

29. When to provide

Education at reduced cost

30. Assessing varieties of DLE in

The world.

31. In designing DLE packages $\quad \begin{array}{llllll}3.32 & 0.79 & \mathrm{~A} & 2.84 & 1.09 & \mathrm{~A}\end{array}$

Table 3, presents the responses of the respondents on the areas e-learning can be applied in DE. Data show that all the variables on the table are areas where e-learning can be applied in DE. This implies that both the distance educators and the learners agreed with all the items as areas of application of e-learning in DE since each of the items has a means score of 2.5 and above.

Hypothesis 1: There is no significance between the mean rating of educators and learners on the competencies required for application of e-learning in DE. 
Table 4

Summary of t-test result on the difference between the mean ratings of educators and learners on required competencies for application of e-learning in DE.

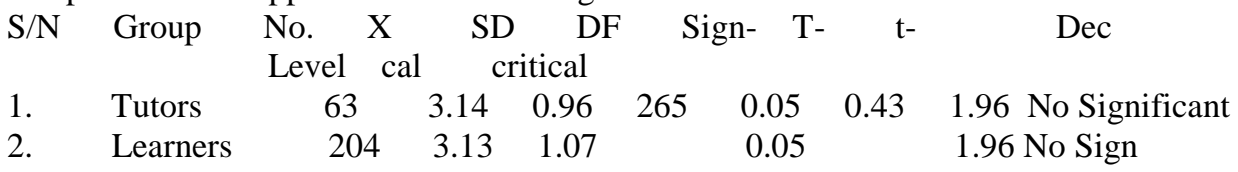

Table 4 indicates that the calculated value of 0.43 is less than the table value of 1.96 at 265 degree of freedom. The data on the table therefore, show that null hypothesis is upheld - implying that there is no significant difference between the mean ratings of distance educators and distance learners on the competencies required for the application of e-learning in DE.

\section{Discussion}

Table one, showed that all the items were keyboard competencies required by distance educators to be able to apply e-learning in distance education. It showed that a good knowledge or mastery of the keyboard will make for easy use of the computer. Thus teachers who lack the competencies of utilizing the computer might find it difficult in operating computer hardware such as keyboard and connecting to the internet.

Table two showed that the items were accepted as competency required by distance educators to enable them upload and download instructional materials.

To upload an instructional material on net requires that one is at home with the competency of arranging either the topic or title and body of the write-up to upload to the Net. One will also possess the ability to select a file or folder, be able to create a temporary file/folder by opening the windows explorer, possess the ability to browse freely on the net, possess the ability to design a web page and choose the correct internet explorer etc. Possession of these competencies and many more will make the distance educator to be at ease with the internet which will in turn facilitate the application of e-learning in DLE. If e-learning is applied in DLE, education would have been democratized to people in various works of live.

Finding three, revealed that e-learning can be applied in DLE in many areas. For instance, in the area of creating greater varieties of learning resources, in creating interactive learning environment in the areas of teaching and training on-line, areas that make learner to acquire and receive results within seconds or minutes (i.e.) in the area of feedback, it also can be applied to cater for personal interest, reduction of cost etc. Once the distance educator possesses these competencies, applying e-learning in DLE will be effective and the optimization of DLE will also be possible. This finding is consistent with that of Hedge \& Hayward (2004) that e-learning is an innovative approach for delivery electronically mediated well designed learner centered interactive learning environment to anyone, anywhere and anytime by utilizing the internet and digital technologies concert with instructional design principles.

The result of the t-test on the difference between the mean ratings of distance educators and learners on required competencies on application of e-learning in DLE showed that between the two groups is not significant. This result is suggesting that once one possesses quality and proficiency, it expressed competency; one will be enable to apply e-learning in every aspect of learning. In conclusion, e-learning can be effectively applied in DLE and any other areas if computer education is emphasized in every aspect of education.

\section{Recommendations}

1. Distance educators should be familiar with the various keyboards and their functions, in order to be able to function effectively in the world of information and Communication Technology which e-learning is part and can be useful to organizers and stakeholders in DLE.

2. The distance educators and learners should be knowledgeable on how to use the internet to be able

3. Computer education should be made compulsory by the considered bodies for both staff and students in all the Nigerian institutions of learning as this, will aid e-learning and its application in DLE and other areas of importance.

4. Donor agencies should assist distance educators by donating computers and internet components to facilitate the effective application of e-learning in DLE.

\section{References}

[1]. Blackmore, C., van Deurzen, E., \& Tantam, D. (2007), "Therapy training online: Using the internet to widen access to training in mental health issues", In T. Stickley \& T. Basset (Eds.) Teaching Mental Health (pgs. 337-352). Hoboken, NJ: John Wiley \& Sons, Ltd.

[2]. Dichantz, H. (2001), "E-learning, a linguistic, psychological and pedagogical analysis of a misleading term", Paper presented at the 20th ICDE World Conference in Düsseldorf 2001.

[3]. Hedge, N. and Hayward, L. (2004), "Redefining roles, University e-learning contributing to Life-long learning in a networked world",

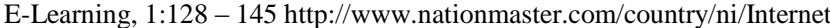

[4]. International Labour Organization (2003), Inter-American Research and Development Centre, Learner, M. (2008) Learn the Net (www.learnthenee.com) June, 16. 
[5]. Jedlicka, J. S., Brown, S. W., Bunch, A. E., \& Jaffe, L. E. (2002), "A comparison of distance education instructional methods in occupational therapy", Journal of Allied Health, 31(4), 247-251.

[6]. Lucia, Anntoinette D. and Lepsinger, Richard (1999), "The Art and Science of Competency Models", Jossey-Bass / Pfeiffer, San Francisco, 1999, ISBN 0-7879-4602-8

[7]. Oblinger, Diana G. (2000). "The Nature and Purpose of Distance Education", The Technology Source (Michigan: Michigan Virtual University) (March/April). Retrieved 23 January 2011

[8]. Onugha, I. (2006) Computer Overview, Window a FileManagementStaffICTCapacityBuilding Programme

[9]. Orr, P. (2010). Distance supervision: Research, findings, and considerations for art therapy. The Arts in Psychotherapy, 37, 106-111

[10]. Schaayan, J. (2000). "Learning of the Internet Deutschland www.studeeren.im.net.ed,june16

[11]. Uzodinma, U. (2006). The Use of Information \& Communication Technology in Secondary Schools in Nigeria: Problems \& Prospects. Information \& Communication Technology in the Service of Education. Eze, D.N. (ED)Nsukka. University Trust Publishers 